\title{
The Phytostabilization of Mercury (Hg) in Ipomoea reptans Poir Plants from Polluted Soil
}

\author{
Rismawaty Sikanna ${ }^{1}$, Dede Sutriono ${ }^{2}$, Prismawiryanti ${ }^{3}$ \\ ${ }^{1}$ Department of Chemistry, Faculty of Science and Technology, Universitas Islam Negeri \\ Alauddin Makassar, Indonesia. 92113 \\ ${ }^{2}$ Sekolah Tinggi Ilmu Kesehatan Bina Mandiri Gorontalo, Indonesia. 96128 \\ ${ }^{3}$ Department of Chemistry, Faculty of Mathematics and Natural Sciences, Universitas \\ Tadulako, Indonesia. 94148 \\ \{rismasikanna@gmail.com ${ }^{1}$, rismawaty.sikanna@uin-alauddin.ac.id ${ }^{1}$, dsutriono@gmail.com², \\ prismawiryanti@gmail.com $\left.{ }^{3}\right\}$
}

\begin{abstract}
Research on the phytostabilization of mercury in Ipomoea reptans Poir plants has been done. This study aims to determine the effect of planting age on the ability of mercury uptake by leaves of Ipomoea reptans Poir, knowing the mercury concentrations distributed on the leaves of Ipomoea reptans Poir and determine the ability of Ipomoea reptans Poir plants as mercury hyperaccumulators. Planting age used in this study consisted of four times, namely: 2, 3, 4 and 5 weeks. The concentration of planting media used is $25 \mathrm{ppm}$, $50 \mathrm{ppm}, 75 \mathrm{ppm}$ and $100 \mathrm{ppm}$. The results of the analysis showed that the maximum absorption time occurred in the third week with absorption concentrations of $145.484 \mu \mathrm{g} / \mathrm{gr}$ dry weight, and that value was an indicator that Ipomoea reptans Poir was a mercury hyperaccumulator.
\end{abstract}

Keywords: Mercury, Leaves of Ipomoea reptans Poir, Planting age, Hyperaccumulator.

\section{Introduction}

Mercury $(\mathrm{Hg})$ derived from both natural and anthropogenic sources enters the global $\mathrm{Hg}$ cycle and is ultimately wet or dry deposited into either aquatic or terrestrial ecosystems. Notably, $\mathrm{Hg}$ is very persistent in soils, lakes and oceans [1];[2] and its mobility depends on the chemical speciation, which is a function of several soil parameters and their interactions [3]. Pollution of mercury in the soil can occur due to the weathering process of mineralized rocks or due to drying of gold processing. Distribution of mercury pollution can occur in gold mining in the stages of grinding, washing and drying. Milling causes mercury to split into fine grains whose properties are difficult to separate, so that it can escape from drum or spindle [4].

Some studies say that the amount of mercury lost after the amalgamation process can reach $5-10 \%$ [5]. Although tailings can be processed or recycled, there is a high probability that the mercury concentrations found in the final tailings are still large [6]. The use of mercury for a long time can have a significant impact on health problems to humans [7]. 
Environmental damage by metal mercury is caused by the disposal of amalgamically treated gold processing tailings, in which mercury undergoes certain treatment in the form of rotation, collision or friction so that it will form amalgam with metals ( $\mathrm{Au}, \mathrm{Ag}, \mathrm{Pt}$ ) and partially lost in the process [8].When a hazardous or toxic substance such as mercury $(\mathrm{Hg})$ has contaminated the soil surface, it can evaporate, be washed away by rainwater and will enter the soil. Pollution that enters the soil then settles (precipitates) as a chemical that is toxic to the soil. Toxic substances in the soil can have a direct impact on humans when in direct contact or can contaminate ground water and air[9].Therefore,techniques are imperatively needed to reduce the level of toxic metals in contaminated soils, particularly those used for crop production.

Many methods are already being used to clean up the environment from these kinds of contaminants, but most of them are costly and far away from their optimum performance. The chemical technologies generate large volumetric sludge and increase the costs [10]; But these methods are not efficient because they will cause new problems over time. One alternative method that can be used is remediation [11]. Remediation of heavy metals by the phytoremediation method was the use of plants to clean up the polluted environment that had been used several decades ago because of low costs, non-invasive choices or a complementary technology based on the method remediation. Benefits of phytoremediation are to eliminate or immobilize metals in contaminated soil using plants [12]. The establishment of green plants on contaminated soil proves more economical in many ways: (i) phytostabilization; (ii) phytoextraction of precious metals like $\mathrm{Hg}, \mathrm{Ag}$ and $\mathrm{Ni}$; (iii) suistanable land management [13]. Phytostabilization or phytoimmobilization refers to the use of plant having ability to decrease the mobility or and bioavaiabiity of a metal [11]. In previous studies plants from the genus Ipomoea can be used to remediate soil contaminated with heavy metals.

Walker et al. reported that Ipomoea alpina is a copper $(\mathrm{Cu})$ hyperaccumulator plant with the ability to accumulate the metal up to a concentration of $12,300 \mathrm{ppm}$ in its leaves [14]. In studies that have not been carried out handling heavy metals especially $\mathrm{Hg}$ using Ipomoea plants. Therefore, based on the description above, the remediation of mercury $(\mathrm{Hg})$ in the soil will be investigated using Ipomoea reptans Poir plants, where the plant species are genetically very diverse in their ability to be tolerant or intolerant of the elements not essential such as Argon $(\mathrm{Ag})$, aluminium $(\mathrm{Al})$, cadmium $(\mathrm{Cd})$, mercury $(\mathrm{Hg})$, lead $(\mathrm{Pb})$, platinum $(\mathrm{Pt})$ in amounts that can poison [9].

\section{Material and Methods}

The first stage, Ipomoea reptans Poir seeds are soaked with water for 4 hours before being put in a pot. Then selected based on the shape and size. Planting is done by entering each 1 seed in each potwas made with concentrations of $25 \mathrm{ppm}, 50 \mathrm{ppm}, 75 \mathrm{ppm}$ and $100 \mathrm{ppm}$ respectively, and left for 2 weeks. Plants are watered every day in the afternoon and added with urea after 1 week of planting.

\subsection{Sample preparation}

Ipomoea reptansPoir plants are harvested one week after the plant grows, each done once every week until the 4 th planting age ( 5 weeks). Plants that have been harvested are then washed using water and cleaned again with distilled water until clean. Separated leaves, from Ipomoea reptans Poir plants, aerated, and dried in an oven for 24 hours at $60^{\circ} \mathrm{C}$, then cooled in a desiccator. 
Samples (leaves of Ipomoea reptans Poir) were first destroyed, by means of dried leaves weighed, $3 \mathrm{ml}$ of $65 \%$ nitric acid was added and heated on a hotplate at a temperature of about $95^{\circ} \mathrm{C}$. This process takes place in a fume hood, heating is carried out until the solution becomes somewhat dry, the solution is lifted and cooled. After cooling, the sample solution is added to the appropriate amount of aquadest. Filtered with Whatman filter paper No.42, the filtrate from the filtered product is put in a $100 \mathrm{ml}$ measuring flask and the volume is adjusted to the limit mark.

\subsection{Analysis of mercury (Hg) in leaves of Ipomoea reptans Poir}

$100 \mathrm{ml}$ of each standard solution added $10 \mathrm{ml}$ of $10 \mathrm{~N}$ sulfuric acid $\left(\mathrm{H}_{2} \mathrm{SO}_{4}\right)$ and $5 \mathrm{ml}$ of $\mathrm{SnCl}_{2}$ solution then measured by atomic absorption spectrophotometer (AAS) at a wavelength of $253.7 \mathrm{~nm}$ without flameless using a hybrid vapor generator, this is because mercury metal is easy yawning. Samples that were ready to be tested were treated similarly to the treatment of a standard solution which was added $10 \mathrm{ml}$ of $10 \mathrm{~N} \mathrm{H}_{2} \mathrm{SO}_{4}$ and $5 \mathrm{ml}$ of $\mathrm{SnCl}_{2}$ solution then measured using AAS.

Determination of concentration and weight of mercury (Hg) using eq. (1) and (2):

$$
\text { concentration of } \mathrm{Hg}(\mu \mathrm{g} / \mathrm{gram})=\frac{\text { ppb curve } \times \mathrm{V}(\text { Liter })}{\mathrm{w}(\text { gram })} \times \mathrm{DF}
$$

$$
\text { Weight of } \mathrm{Hg}(\mathrm{mg})
$$

Where: ppb curve is concentration of AAS results ( $\mu \mathrm{g} / \mathrm{Liter}$ ); ppm calculated (concentration of $\mathrm{Hg}$ ) is concentration of calculation result ( $\mu \mathrm{g} / \mathrm{gram})$; $\mathrm{V}$ is sample volume (Liter); $\mathrm{w}$ is sample weight (gram); DF is dillution factor

\section{Results and Discussion}

\subsection{Effect of planting age on the mercury content distributed on the leaves of Ipomoea reptansPoir}

The concentration of mercury $(\mathrm{Hg})$ in the leaves of Ipomoea reptans Poir is obtained by measurement using AAS. Leaf samples of Ipomoea reptans Poir plants were prepared in advance with the acidification process using a solution of nitric acid $\left(\mathrm{HNO}_{3}\right)$ to dissolve the metals found in the leaves.

The results of the analysis of the effect of planting time on mercury accumulation $(\mathrm{Hg})$ contained in Ipomoea reptans Poirplants are shown in appendix table 1 which is the concentration data with three replications and shows different concentrations in each replica pot. In table 1, it can be seen that the concentration of mercury $(\mathrm{Hg})$ distributed on the leaves of Ipomoea reptans Poir plants increases with increasing age of planting and reaches the maximum time at the second planting age of 3 weeks. This increase in concentration is the same as the results of a study conducted by Liong which used Ipomoea reptans Poir plants with an increase in optimum weight accumulation of $\mathrm{Cd}$ (II), $\mathrm{Cr}$ (IV), $\mathrm{Pb}$ (II) at soil concentration in the third week and a decrease in the following week [15]. 
Table 1. Results of mercury concentrations distributed to leaves of Ipomoea reptans Poir ( $\mu \mathrm{g}$ / gram dry weight (drwt) of samples) by the effect of planting age

\begin{tabular}{|c|c|c|c|c|c|}
\hline \multirow{2}{*}{$\begin{array}{c}\text { Planting } \\
\text { age }(\mathrm{T})\end{array}$} & \multicolumn{3}{|c|}{ Concentration of $\mathrm{Hg}(\mu \mathrm{g} / \mathrm{gr} \mathrm{drwt})$} & \multirow{2}{*}{$\begin{array}{l}\text { Totalconc. } \\
(\mu \mathrm{g} / \mathrm{gr} \text { drwt })\end{array}$} & \multirow{2}{*}{$\begin{array}{l}\text { Average conc. } \\
(\mu \mathrm{g} / \mathrm{gr} \text { drwt })\end{array}$} \\
\hline & I & II & III & & \\
\hline T 1 & 64.9148 & 55.9078 & 54.8016 & 175.6242 & 58.5414 \\
\hline Т 2 & 125.3716 & 146.6679 & 164.4125 & 436.452 & 145.4840 \\
\hline T 3 & 83.6128 & 78.3381 & 52.1233 & 214.0742 & 71.35807 \\
\hline $\mathrm{T} 4$ & 31.0988 & 31.1328 & 8.0448 & 70.2764 & 23.42547 \\
\hline Total & & & & 896.4268 & 298.8089 \\
\hline
\end{tabular}

$\mathrm{T} 1=1$ st planting age $(2$ weeks $) ; \mathrm{T} 2=2$ nd planting age $(3$ weeks $) ; \mathrm{T} 3=3 \mathrm{rd}$ planting age $(4$ weeks); $\mathrm{T} 4=4$ th planting age $(5$ weeks $)$; Conc. $=$ concentration

The results of the concentration measurement data (table 1) were processed using analysis of variance (table 2) and the results showed that planting age had a very significant effect on increasing mercury distribution on the leaves of Ipomoea reptans Poir, where the results showed F stat.is 36.1722 greater than $\mathrm{F}$ table $(\alpha 0.05)$ of 4.07 .

\section{Sum of squares (SS):}

$$
\begin{gathered}
\text { TS }=\frac{896.4268^{2}}{4 \times 3}=66965.0839 \\
\text { SS Total }=\left(\begin{array}{c}
\left.64.9148^{2}+\ldots+8.0448^{2}\right)-\mathrm{TS} \\
=25484.9569
\end{array}\right. \\
\text { SS between }=\frac{\left(175.6242^{2}+\cdots+70.2764^{2}\right)}{3}-\mathrm{TS}=23735.1639 \\
\text { SS (within) }=\text { SS Total }- \text { SS (between) }=1749.793
\end{gathered}
$$

Table 2. Analysis of variance (F test) of the effect of planting age on mercury concentrations distributed on the leaves of Ipomoea reptans Poir

\begin{tabular}{ccccccc}
\hline \multirow{2}{*}{ VS } & df & SS & \multirow{2}{*}{ MS } & F & \multicolumn{2}{c}{ F Table } \\
\cline { 3 - 7 } & & & & & $\mathbf{0 , 0 5}$ & $\mathbf{0 , 0 1}$ \\
\hline Between & 3 & 23735.164 & 7911.721 & $36.172 * *$ & 4.07 & 7.59 \\
Within & 8 & 1749.793 & 218.7241 & & & \\
Total & $\mathbf{1 1}$ & $\mathbf{2 5 4 8 4 , 9 5 7}$ & & & & \\
\hline$* *$ = significantdifference; VS is variance source; SS is sum of squares; df is degree of freedom; \\
MS is Mean square; F is F calculated.
\end{tabular}


$\mathrm{df}_{\text {(between) }}=\mathrm{a}-1=4-1=3 ; \mathrm{df}_{(\text {within })}=\mathrm{N}-\mathrm{a}=12-4=8 ; \mathrm{df}_{\text {Total }}=\mathrm{df}_{(\text {between })}+\mathrm{df}_{(\text {within })}=$ $8+3=11$.

The average concentration of mercury in the leaves of Ipomoea reptans Poir based on planting age in each dry weight (dr wt), respectively, at the 1st planting age of $58.5414 \mu \mathrm{g} /$ gram; second planting age is $145.484 \mu \mathrm{g} /$ gram; $3 \mathrm{rd}$ planting age is $71.3581 \mu \mathrm{g} / \mathrm{gram}$; and the fourth planting age is $23.4255 \mu \mathrm{g}$ / gram.

In Figure 1, a graph is shown relatonship between the age of planting and the magnitude of the average concentration of mercury distributed to the leaves of Ipomoea reptans Poir.

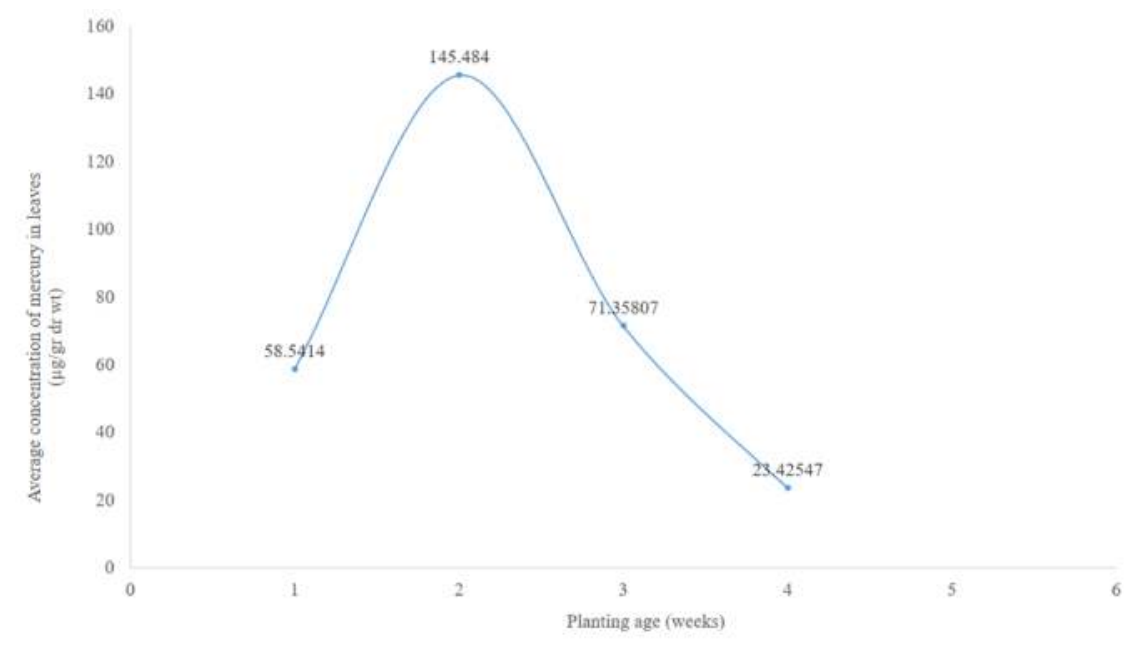

Fig. 1. Graph of the relationship between planting age and the average concentration of mercury $(\mathrm{Hg})$ in leaves of Ipomoea reptans Poir.

From the graph in Figure 1 shows the maximum $\mathrm{Hg}$ distribution occurs at the 2nd planting age ( 3 weeks) and the decrease in concentration occurs at the 3rd planting age (4 weeks) and 4 th planting age ( 5 weeks). This can be caused by plant stress or saturation so that mercury uptake is reduced, which results in very little transfer to the leaf part of the plant that week. This also happens because plants have experienced the toxicity of high concentrations of heavy metals, which interfere with the absorption of these plants [16]; and the death of a plant occurs when plants cannot synthesize phytochelatin, which culminating in inhibition of plant growth until the death of plants [12].

The results of the increase and decrease in mercury uptake that occurred in this study were supported by several results of heavy metal phytoremediation studies, including the results of the study by Munawar et al. who used mangroves in the absorption of heavy metals $\mathrm{Hg}$ stated that mangroves had increased accumulation of $\mathrm{Hg}$ heavy metals until the third week, whereas in the fourth and fifth weeks they had decreased levels of heavy metals. This can happen because mangroves are stressed or saturated, so that heavy metal absorption of mercury is not maximal while transport continues to take part in other plants, namely stems and leaves [17]. 
3.2 Effect of concentration of planting media on mercury $(\mathrm{Hg})$ concentrations distributed on leaves of Ipomoea reptans Poir

Data on the amount of Mercury $(\mathrm{Hg})$ absorbed in Ipomoea reptans Poir plants as a function of the concentration added to the planting media can be seen in appendix table 3 and figure 2 .

Table 3. The concentrations of $\mathrm{Hg}$ distributed on the leaves of in Ipomoea reptansPoirby the influence of the concentration of planting media

\begin{tabular}{|c|c|c|c|c|c|}
\hline \multirow{2}{*}{$\begin{array}{l}\text { Concentration of } \\
\text { planting } \\
\text { media(C) }\end{array}$} & \multicolumn{3}{|c|}{ Concentration of $\mathrm{Hg}(\mu \mathrm{g} / \mathrm{gr}$ drwt $)$} & \multirow{2}{*}{$\begin{array}{l}\text { Total conc. } \\
\text { ( } \mu \mathrm{g} / \mathrm{gr} \text { drwt) }\end{array}$} & \multirow{2}{*}{$\begin{array}{l}\text { Average conc. } \\
(\mu \mathrm{g} / \mathrm{gr} \text { drwt })\end{array}$} \\
\hline & $\mathrm{I}$ & II & III & & \\
\hline $\mathrm{C} 1$ & 75.5976 & 8.3361 & 14.7976 & 98.7313 & 32.91043 \\
\hline $\mathrm{C} 2$ & 27.6894 & 47.0969 & 37.6542 & 112.4405 & 37.48017 \\
\hline $\mathrm{C} 3$ & 24.0424 & 62.5153 & 37.5825 & 124.1402 & 41.38007 \\
\hline $\mathrm{C} 4$ & 125.3716 & 146.6679 & 164.4125 & 436.4520 & 145.4840 \\
\hline Total & & & & 771.764 & 257.2547 \\
\hline
\end{tabular}

$\mathrm{C} 1=25 \mathrm{ppm}$ (Concentration of $\mathrm{Hg}$ in the planting media); $\mathrm{C} 2=50 \mathrm{ppm} ; \mathrm{C} 3=75 \mathrm{ppm} ; \mathrm{C} 4=100$ ppm.

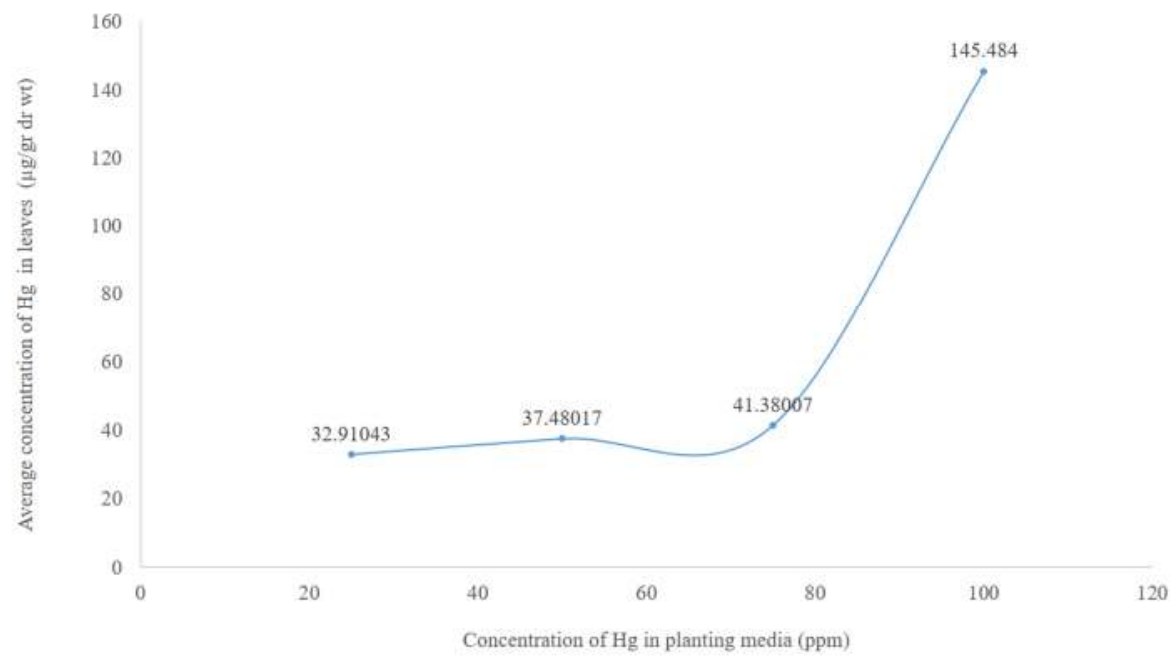

Fig. 2. Graph of the relationship of the average concentration of $\mathrm{Hg}$ in leaves of Ipomoea reptans Poirplants on the magnitude of the concentration of $\mathrm{Hg}$ of planting media 
In Figure 2, it can be seen that the amount of mercury $(\mathrm{Hg})$ that can be absorbed by plants and distributed in leaves increases with increasing metal concentrations found in the growing media. This can be caused because the planting media with a concentration of $100 \mathrm{ppm}$ metal population density is greater than at a concentration of $25 \mathrm{ppm}$. The higher the amount of $\mathrm{Hg}$ in the plantingg media, the higher the concentration absorbed by plants [16]. According with Wulandari et al. study says that he amount of metal concentration added to the planting media will affect the absorption of metals by plants, and the amount of metal concentration added in the planting media is directly proportional to the concentration of the metal absorbed [11];[18].

The average mercury concentration obtained from the results of this analysis is as follows: concentration of $25 \mathrm{ppm}(\mathrm{C} 1)$ of $32.9104 \mu \mathrm{g} /$ gram; concentration of $50 \mathrm{ppm}(\mathrm{C} 2)$ of 37.4802 $\mu \mathrm{g}$ / gram; concentration of $75 \mathrm{ppm}$ (C3) $41.3801 \mu \mathrm{g} /$ gram and concentration of $100 \mathrm{ppm}(\mathrm{C} 4)$ of $145.484 \mu \mathrm{g} /$ gram. The difference in the concentration data after analysis of variance (table 4), shows F count $>\mathrm{F}$ table $5 \%$ and $1 \%$ (F count $15,792 \mathrm{~F}$ table $5 \% 4.07$ and $\mathrm{F}$ table $1 \%$ of 7.59 ). This means that the high concentration of planting media has a very significant effect in increasing the absorption of mercury distributed on the leaves of Ipomoea reptans Poir.

Tabel 4.The analysis of variance (F test) of the concentration of the planting media on the concentration of mercury distributed to the leaves of Ipomoea reptans Poir

\begin{tabular}{ccccccc}
\hline \multirow{2}{*}{ VS } & df & SS & \multirow{2}{*}{ MS } & F & \multicolumn{2}{c}{ F Table } \\
& & & & & $\mathbf{0 , 0 5}$ & $\mathbf{0 , 0 1}$ \\
\hline Between & 3 & 26462.3185 & 8820.7728 & $15.792^{* *}$ & 4.07 & 7.59 \\
Within & 8 & 4468.4504 & 558.5563 & & & \\
Total & $\mathbf{1 1}$ & $\mathbf{3 0 9 3 0 . 7 6 8}$ & & & & \\
\hline & $* *$ significant difference.
\end{tabular}

\subsection{Ipomoea reptans Poir as a hyperaccumulator}

All plants have the ability to absorb metals but in varying amounts. A number of plants from many families have been shown to have hypertolary properties, which are able to accumulate metals with high concentrations in the root tissue and leaves so that they are hyperaccumulators [8]. Some of the characteristics of hyperaccumulator plants are rapid growth, large biomass, including yields and being able to accumulate metals in the leaves of plants [1]; [19]. From the results of this study, the value of good mercury $(\mathrm{Hg})$ withdrawal that was influenced by the age of planting and concentration gave a value greater than $10 \mu \mathrm{g} / \mathrm{gr}$ drwt (table $5 \& 6$ ), with mercury concentration $(\mathrm{Hg})$ being withdrawn for the effect of the third week of mercury contamination $(\mathrm{Hg}) 100 \mathrm{ppm}$ is $145,484 \mu \mathrm{g} / \mathrm{gr}$ drwt, thus it can be said that Ipomoea reptans Poir is a hyperaccumulator of mercury. According to this conventional criterion, a hyperaccumulator should tolerate and accumulate in the shoot tissue more than $10 \mathrm{mg} \mathrm{kg}^{-1}$ of $\mathrm{Hg}$ [20]. 
Table 5. The weight of mercury is distributed on the leaves of Ipomoea reptans Poir plants by the influence of planting age

\begin{tabular}{cccccr}
\hline \multirow{2}{*}{ Planting age (T) } & \multicolumn{3}{c}{$\begin{array}{c}\text { Weight of Hg } \\
(\mathrm{mg})\end{array}$} & $\begin{array}{c}\text { Total } \\
\text { weight } \\
(\mathrm{mg})\end{array}$ & $\begin{array}{c}\text { Average } \\
\text { weight }(\mathrm{mg})\end{array}$ \\
\cline { 2 - 4 } & $\mathrm{I}$ & II & III & & \\
\hline T1 & 0.0115 & 0.0090 & 0.0116 & 0.0321 & 0.0107 \\
T2 & 0.0200 & 0.0390 & 0.0270 & 0.0860 & 0.0287 \\
T3 & 0.0104 & 0.0281 & 0.0101 & 0.0486 & 0.0162 \\
T4 & 0.0299 & 0.0116 & 0.0312 & 0.0726 & 0.0242 \\
Total & & & & $\mathbf{0 . 1 6 6 7}$ & $\mathbf{0 . 0 5 5 6}$ \\
\hline
\end{tabular}

Table 6. The weight of mercury is distributed to the leaves of Ipomoea reptans Poir plants by the influence of the concentration of planting media

\begin{tabular}{|c|c|c|c|c|c|}
\hline \multirow{2}{*}{$\begin{array}{l}\text { Concentration of planting } \\
\text { media }\end{array}$} & \multicolumn{3}{|c|}{$\begin{array}{l}\text { Weight of } \mathrm{Hg} \\
(\mathrm{mg})\end{array}$} & \multirow{2}{*}{$\begin{array}{l}\text { Totalweight } \\
\text { (mg) }\end{array}$} & \multirow{2}{*}{$\begin{array}{c}\text { Average } \\
\text { weight } \\
\text { (mg) }\end{array}$} \\
\hline & I & II & III & & \\
\hline $\mathrm{C} 1$ & 0.0206 & 0.0023 & 0.0056 & 0.0285 & 0.0095 \\
\hline $\mathrm{C} 2$ & 0.0059 & 0.0110 & 0.0072 & 0.0241 & 0.0080 \\
\hline $\mathrm{C} 3$ & 0.0100 & 0.0120 & 0.0085 & 0.0305 & 0.0102 \\
\hline $\mathrm{C} 4$ & 0.0200 & 0.0390 & 0.0270 & 0.0860 & 0.0287 \\
\hline Total & & & & 0.1691 & 0.056367 \\
\hline
\end{tabular}

The mechanism of metal accumulation using plants can be determined by calculating the value of bioconcentration factor $(\mathrm{BCF})$ and translocation factor $(\mathrm{TF})$. BCF from plants is a ratio of the ratio of metal concentrations in roots to metal concentrations in the soil, whereas $\mathrm{TF}$ is the ratio of metal concentrations in leaves to concentrations in roots. BCF values are generally greater than one $(\mathrm{BCF}>1)$ while $\mathrm{TF}$ values are generally smaller than one $(\mathrm{TF}<1)$ [21].

Data from the calculation of TF values for variations in harvest age are shown in table 7 and figure 3 below:

Table7.The value of TF by influence of planting age and concentration of planting media

\begin{tabular}{|c|c|c|c|c|c|}
\hline & \multicolumn{3}{|c|}{ Weight of $\mathrm{Hg}(\mathrm{mg})$} & \multirow{2}{*}{$\begin{array}{l}\text { Total } \\
\text { (mg) }\end{array}$} & \multirow{2}{*}{$\begin{array}{l}\text { Average } \\
\text { weight } \\
\text { (mg) }\end{array}$} \\
\hline & I & II & III & & \\
\hline \multicolumn{6}{|c|}{ a. Planting age (T) } \\
\hline $\mathrm{T} 1$ & 0.1675 & 0.1583 & 0.0927 & 0.4185 & 0.1395 \\
\hline $\mathrm{T} 2$ & 0.0787 & 0.1665 & 0.1549 & 0.4001 & 0.1334 \\
\hline T3 & 0.2414 & 0,1078 & 0,1662 & 0,5154 & 0.1718 \\
\hline T4 & 0.0897 & 0.0429 & 0.0256 & 0.1582 & 0.0527 \\
\hline Total & & & & 1.4922 & 0.4974 \\
\hline \multicolumn{6}{|c|}{$\begin{array}{l}\text { b. Concentration of } \\
\text { planting media }(C)\end{array}$} \\
\hline $\mathrm{C} 1$ & 0.4856 & 0.0886 & 0.0614 & 0.6356 & 0.2118 \\
\hline $\mathrm{C} 2$ & 0.1192 & 0.1136 & 0.5006 & 0.7334 & 0.2444 \\
\hline $\mathrm{C} 3$ & 0.1189 & 0.2010 & 0.0806 & 0.4005 & 0.1335 \\
\hline $\mathrm{C} 4$ & 0.0787 & 0.1665 & 0.1549 & 0.4001 & 0.1334 \\
\hline Total & & & & 2.1696 & 0.7231 \\
\hline
\end{tabular}




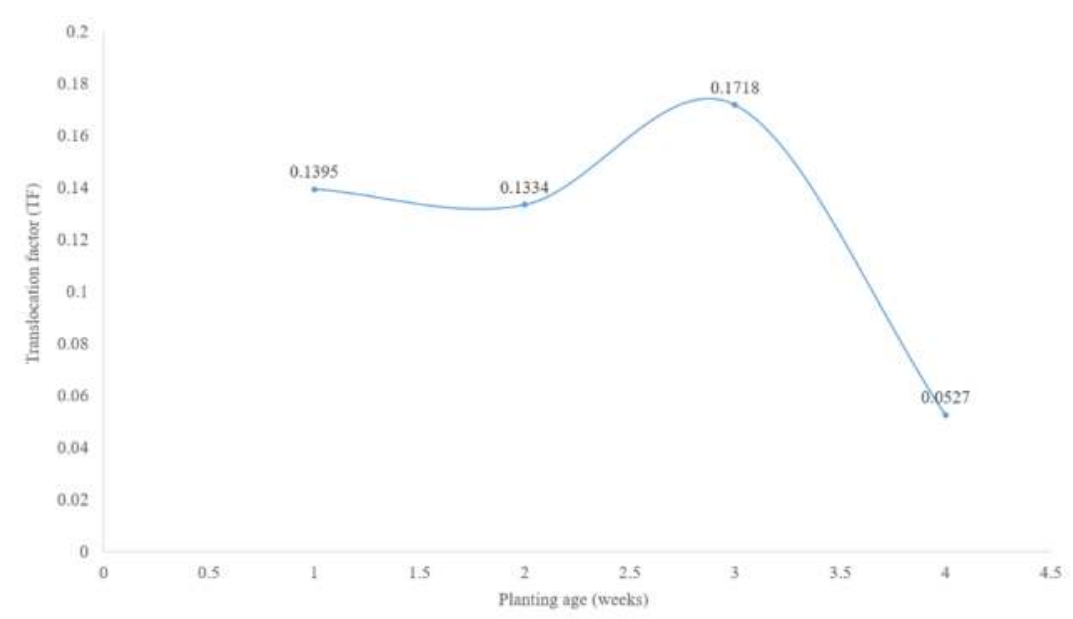

Fig. 3. Graph of relationship between TF value and planting age

The results of the analysis show that both variations in time and concentration, the accumulation of mercury $(\mathrm{Hg})$ which is distributed in parts of the leaves of the plant has a smaller concentration. The results of the analysis of plant roots BCF values in Khairuddin's study showed a value greater than one $(\mathrm{BCF}>1)$ for time variations and concentration variations [22]. The results and TF values obtained indicate a relationship between BCF and TF inversely. The value of TF on the effect of planting age and the concentration obtained indicates that Ipomoea reptans Poir has the ability to accumulate mercury $(\mathrm{Hg})$ by phytostabilization [11].

\section{Conclusion}

The concentration of mercury $(\mathrm{Hg})$ distributed on the leaves of Ipomoea reptans Poir is directly proportional to the concentration of the planting medium, with the maximum concentration obtained at the second planting age (3 weeks) at an average of 145,484 $\mu \mathrm{g}$ / gram dry weight of the leaves.

Mercury accumulation $(\mathrm{Hg})$ through a phytostabilization process in leaves greater than 10 $\mu \mathrm{g}$ / gr dry weight so that Ipomoea reptans Poir plants can be determined as hyperaccumulators.

\section{References}

[1] Padmavathiamma, P.K. and Li, L.Y. Phytoremediation technology: Hyperaccumulation metals in plants. Water. Air. Soil Pollut. 184(1) pp.105-126.doi: 10.1007/s11270-007-9401-5(2007)

[2] Tangahu, B.V., Sheikh Abdullah, S.R., Basri, H., Idris, M., Anuar, N., and Mukhlisin, M. A review on heavy metals $(\mathrm{As}, \mathrm{Pb}$, and $\mathrm{Hg}$ ) uptake by 56 plants through phytoremediation. Int. J. Chem. Eng. Vol. 2011 pp. 1-31. doi: 10.1155/2011/939161(2011)

[3] Yin, Y., Allen, H.E., Huang, C.P., and Sanders, P.F.:Kinetics of Mercury (II 57) Adsorption and Desorption on Soil. Environ. Sci. Technol. 31 (2) pp. 496-503 doi: org/10.1021/es9603214(1997)

[4] Juliawan, N. Widiayatna, D. and Jatim, J. Pendataan Penyebaran Unsur Merkuri Pada Wilayah Pertambangan Cibaliung, Kabupaten Pandegelan, Provinsi Banten. Hasil Kegiatan Subdit Konservasi TA. (2005). 
[5] Herman, D. Z.: Tinjauan terhadap tailing mengandung unsur pencemar Arsen (As), Merkuri (Hg), Timbal $(\mathrm{Pb})$, dan Kadmium (Cd) dari sisa pengolahan bijih logam. J. Geologi Indonesia vol. 1 (1) pp. 31-36.doi: org/10.17014/ijog.1.1.31-36 (2006)

[6] Wang J, Feng X, Anderson CWN, Xing Y and Shang L. :Remediation of mercury contaminated sites-a review. Journal of Hazardous Materials 221-222 pp.1-18.doi: org/10.1016/j.jhazmat.2012.04.035 (2012.)

[7] Wurdiyanto:Merkuri, Bahaya dan Pengukurannya, Buletin Alara. 9 (1\&2) pp.19-25. (2007).

[8] Hidayati, N.: Fitoremediasi dan Potensi Tumbuhan Hiperakumulator. J. Hayati vol. 12 (1) pp. 35-40. doi:org/10.1016/S1978-3019(16)30321-7(2004).

[9] T. C. Chang, S. J. You, B. S. Yu, C. M. Chen, and Y. C. Chiu,: Treating high-mercury-containing lamps using fullscalethermal desorption technology. Journal of Hazardous Materials, vol. 162 ( 23) pp. 967-972. doi:org/10.1016/j.jhazmat.2008.05.129 ( 2009).

[10] R. Rakhshaee, M. Giahi, and A. Pourahmad. : Studying effect of cell wall's carboxyl-carboxylate ratio change of Lemna minor to remove heavy metals from aqueous solution. Journal of Hazardous Materials, vol. 163 (1), pp. 165-173. doi:org/10.1016/j.jhazmat.2008.06.074 (2009).

[11] Sharwar, N., M. Imran, M. R. Shahen, W. Ishaq, A. Kamran, A. Matloob, A. Rehim, and S. Hussain. : Phytoremediation strategies for soils contaminated with heavy metals: Modifications and future perspectives. Chemosphere. 171.pp. 1-12. doi: 10.1016/j.chemosphere.2016.12.116 (2016)

[12] R. R. Hinchman, M. C. Negri, and E. G. Gatliff. : Phytoremediation: using green plants to clean up contaminated soil, groundwater, and wastewater. Argonne National Laboratory Hinchman, Applied Natural Sciences, Inc, 1995, http://www .treemediation.com/Technical/Phytoremediation (2000).

[13] Ali, H. Khan, E., Sajad, M.A. : Phytoremediation of heavy metals- Concepts and application, Chemosphere 91 pp.869-881. doi: org/10.1016/j.chemosphere.2013.01.075 (2013).

[14] T. J., Purakayashta and PK. Chhonkar. : Phytoremediation of heavy metal contaminated Soil. Soil Heavy Metals,Springer, pp.389-430. ISBN: 978-3-642-02436-8. doi: org/10.1007/978-3-64202436-8 (2010).

[15] Liong, S.: Mekanisme Fitoakumulatif ion Cd(II), Cr(IV), dan Pb(II) pada Kangkung Darat (Ipomoea reptans Poir). http://repository.unhas.ac.id/handle/123456789/1249. (2012).

[16] Rudy, S.: Fitoremediasi Logam $\mathrm{Cu}$ dan Zn dengan Tanaman Eceng Gondok. Logika, 2 (2). doi: 10.20885/logika.vol2.iss2.art4 (2005).

[17] Rina. : Kemampuan Tanaman Mangrove Untuk Menyerap Logam Berat Merkuri (Hg) dan Timbal (Pb) (http://eprints.upnjatim.ac.id/910/1/file1.pdf (2010).

[18] Wulandari, R., T. Purnomo and Winarsih : The Ability of Water Spinach (Ipomoea aquatica) to Absorb Cadmium (Cd) in Different Concentration and Exposure time. http://ejournal.unesa.ac.id/index.php/lenterabio ISSN: 2252-3979

[19] Hardiani, H.: Potensi Tanaman dalam Mengakumulasi Logam $\mathrm{Cu}$ pada Media Tanah Terkontaminasi Limbah Padat Industri Kertas. J. Makara Sains vol. 44 (1), pp. 27 - 40. doi: 10.25269/jsel.v44i01.147 (2009).

[20] Baker, A.J.M., S.P. Mcgrath, R.D. Reeves and J.A.C. Smith. : Metal hyperaccumulator plants: A review of the ecology and physiology of a biological resource for phytoremediation of metal-polluted soils. p. 85-108. In: Phytoremediation of Contaminated Soil and Water. N. Terry and G. Bañuelos (eds.). Lewis, Boca Raton, Florida, USA.doi: org/10.1201/9781439822654 (2000).

[21] Zu, Y.Q., Y.Li, J.J.Chen, H.Y.Chen, L.Qin and C. Schvartz.: Hyperaccumulation of Pb, Zn and $\mathrm{Cd}$ in herbaceous grown on lead-zinc mining area in Yunnan, China. Environ. Internat.31:755762. doi: 10.1016/j.envint.2005.02.004. (2005)

[22] Khairuddin, K., R. Sikanna, Sabaruddin. : Kajian kemampuan Akar Tanaman Kangkung Darat (Ipomoea reptansPoir) dalam Menyerap Logam Merkuri pada Tanah Tercemar. JurnalKovalen vol. 3 (3) doi: 10.22487/j24775398.2017.v3.i3.9340 pp.303-312 (2017). 
